The Polish Journal of the Arts and Culture. New Series 10

(2/2019): 91-107 [ARTYKUI]

DOI: $10.4467 / 24506249$ PJ.19.013.11985

\title{
Formy erotyzmu. Krytyczny potencjał erotyzmu w polskiej poezji współczesnej
}

\author{
Karol PoręBA
}

\begin{abstract}
Streszczenie
Rok 1989 stanowi symboliczną cezurę w dyskursie o seksualności $\mathrm{w}$ Polsce i istotny moment $\mathrm{w}$ historii erotyku jako gatunku: od konwencjonalnie rozumianego wiersza o tematyce miłosnej, przez wulgarne rozerotyzowanie twórców związanych z środowiskiem „bruLionu”, po wyszukane gry z konwencją, mające na celu wydobycie krytycznego potencjału erotyzmu i zaprzęgnięcie go w dyskusję o charakterze społeczno-politycznym. W artykule autor przedstawia sposoby funkcjonowania erotyzmu, seksualności/seksualizmu i pornografii w polskiej poezji współczesnej jako form oporu, na przykładzie twórczości trojga poetów: Jerzego Jarniewicza, Andrzeja Sosnowskiego i Joanny Oparek. Odnosi się m.in. do kategorii przyjemności tekstu Rolanda Barthes'a, koncepcji pornogramatyki markiza de Sade oraz filozofii Georges'a Bataille'a. Autor pokazuje, w jaki sposób współczesna poezja przekształca klasyczną konwencję erotyku w celach ideologicznych lub programowych.
\end{abstract}

Słowa kluczowe: erotyzm, Jerzy Jarniewicz, Joanna Oparek, polska poezja wspótczesna, pornografia, Andrzej Sosnowski

Karol PoRĘBA krytyk literacki, literaturoznawca, doktorant na Wydziale Filologicznym Uniwersytetu Wrocławskiego, redaktor naczelny Wydawnictwa Ossolineum, zajmuje się przede wszystkim poezją XX wieku i współczesną, socjologią literatury oraz filozofią. Afiliacja: Uniwersytet Wrocławski; ORCID: oooo-0oo2-3230-7723 E-MAIL: karol.poreba@uwr.edu.pl 
Tematem szkicu jest krytyczny potencjał różnych form erotyzmu w poezji polskiej po roku 1989 - począwszy od związanego ze sferą sacrum erotyzmu ekstatycznego, przez biologicznie pojmowaną seksualność, na pornografii literackiej skończywszy. Nie ulega wątpliwości, że rok 1989 stanowi istotną cezurę w rodzimym dyskursie o seksualności, a debiuty kolejnych poetów i poetek związanych ze środowiskiem „bruLionu” doprowadziły do stopniowego odtabuizowania sfery erotycznej w polskiej poezji, czyniąc ją bardziej wulgarną i pozbawioną estetycznego naddatku, charakterystycznego dla erotyków powstających przed „przełomem”.

Pojęcia „erotyzm”, „pornografia” i „seksualizm”/,seksualność” są dziś nadal często stosowane jako synonimy, a przecież mają one odmienny ciężar kulturowy, funkcjonują w różnych kontekstach i afordują inne formy literackie. O ile stawiane na przeciwległych biegunach terminy „erotyzm” i „pornografia” funkcjonują w praktyce językowej jako określenia niewspółmierne względem siebie, o tyle „seksualizm” okazuje się bardziej kłopotliwy. Erotyzm kojarzony jest przede wszystkim z nastrojowością, uczuciem czystym, epifanią - w obiegowej opinii za modelowe reprezentacje erotyzmu w kulturze europejskiej uznaje się tekst biblijnej Pieśni nad Pieśniami oraz Ekstaze świętej Teresy Giovanniego Lorenza Berniniego, interpretowane najczęściej jako alegorie miłości czystej i uwznioślonej, ekstatyczno-epifanijnej. Na antypodach tak rozumianego erotyzmu znajduje się traktowana jako perwersyjna i profaniczna pornografia, o której w kontekście szczególnie interesującej mnie tu pornografii literackiej wyczerpująco pisałam.in. Ewa Stusińska w książce Dzieje grzechu. Dyskurs pornograficzny w polskiej prozie XX wieku. Jak już wspomniałem, najbardziej kłopotliwy z punktu widzenia uzusu wydaje się termin „seksualizm”. Jednoznacznych odpowiedzi w tym względzie nie dają rodzime dyskursy antropologiczno- i krytycznoliteracki. W języku polskim słowo to jest właściwie synonimem leksemu „seksualność”, jednak Mirosław Bańko na internetowych łamach Poradni Językowej PWN wskazuje, że „seksualizm” ma także dodatkowe znaczenie i odsyła do tytułu wartego odnotowania leksykonu autorstwa Jacka Lewinsona pt. Stownik seksualizmów polskich. Objaśnia on wyrazy i wyrażenia związane ze sferą seksualną, zarówno archaizmy, jak i te używane współcześnie. O ile z perspektywy poetologicznej kusząca wydaje się próba wydzielenia swoistych seksualizmów formalnych, które Roland Barthes, komentując koncepcję języka literackiego markiza de Sade, nazywa erotemami, to należy zwrócić jeszcze uwagę na niuans ujawniający się w polszczyźnie bodaj tylko w słowach opisujących 
tożsamość seksualną (np. homoseksualizm, biseksualizm) i mocniej wiążący termin „seksualizm” - w odróżnieniu od biologicznej „seksualności” - z perspektywą antropologiczną.

Krytyczne przyjrzenie się wymienionym przeze mnie pojęciom oraz wskazanie mniej lub bardziej wyraźnych różnic między nimi przydatne jest nie tylko $\mathrm{w}$ badaniach kulturoznawczych, ale też w obszarach literaturoznawstwa oraz filozofii języka. Ważne okazuje się też podczas namysłu nad poezją współczesną, w wypadku której terminy „erotyzm”, „seksualność”/ "seksualizm” i „pornografia” odnosić się mogą nie tylko do tematyki utworu, ale także do form lirycznych, tropów, języka poetyckiego czy - może przede wszystkim - strategii pisarskiej autorki lub autora. Pozwoliłoby to także zaproponować swoisty projekt lektury ponowoczesnego erotyku; erotyku rozumianego nie jako „tekst o tematyce miłosnej” (a należy zaznaczyć, że jest to właściwie jedyny sposób postrzegania erotyku z perspektywy polskiej, rygorystycznej genologii), ale jako utwór wykorzystujący leksykę i formy poetyckie wywodzące się z erotyku do osiągnięcia własnych celów, tzn.: żeby realizować określony program ideologiczny lub formalny. Różnice te - podpierając się tekstami teoretyczno- oraz krytycznoliterackimi, a także pracami z zakresu filozofii dwudziesto- i dwudziestopierwszowiecznej - można zarysować m.in. na przykładach pisarstwa trojga poetów: Jerzego Jarniewicza, Andrzeja Sosnowskiego i Joanny Oparek. Wymienieni twórcy nie wyczerpują oczywiście długiej listy współczesnych pisarek i pisarzy zainteresowanych różnie pojmowaną erotyką, ale nie ulega wątpliwości, że ich sposoby wplatania sfery seksualnej w wiersze znacząco różnią się od siebie i realizują odmienne funkcje, ciążąc - kolejno - bardziej ku erotyzmowi, seksualizmom formalnym lub pornografii literackiej. Znamienne dla poezji Jarniewicza, Sosnowskiego i Oparek jest także to, że erotyzm funkcjonuje w ich twórczości zazwyczaj instrumentalnie, tzn. rzadko jest celem samym w sobie. Należy też zaznaczyć, że nie jest moim zamierzeniem szczegółowe omówienie erotyzmu w dorobku literackim wymienionych pisarzy, a raczej naszkicowanie swoistej mapy „gier erotycznych” w poezji ponowoczesnej oraz ich potencjału krytycznego, a zatem sposobów, w jaki erotyzm może być formą oporu przeciwko różnie rozumianym konwencjom społecznym.

Erotyzm rzadko ciąży ku obscenie. Wątki związane z cielesnością eksplikuje nie wprost, w sposób subtelny i często zawoalowany. Bliższy jest perspektywie prywatnej i zazwyczaj akcentuje nastrojowość oraz różnego rodzaju napięcia: także - co szczególnie interesujące z perspektywy krytyki 
poezji - napięcia między słowami (jukstapozycje, metafory), wersami (przerzutnie, wersyfikacja, podział na strofy) czy strukturalne (pomiędzy wierszami w tomie, tytułem a treścią wiersza itp.). W poezji współczesnej erotyzm języka czy formy wierszowej podporządkowany jest często właśnie konkretnym funkcjom poetyckim, wywołaniu określonych wrażeń u odbiorcy. Ujawnia się to na przykład w wielokrotnie opisywanej przez Barthes'a przyjemności obcowania z tekstem. Autor Mitologii stwierdzał, że pisanie (a warto przypomnieć, że także proces lektury francuski filozof uważał za akt czysto twórczy, właściwie nie oddzielając go od pisania) związane jest z „wyobraźnią chciwą przyjemności słów” (Barthes 2009, 19-20); że jest marzeniem o usuwalności wyalienowania języka. Styl rozumiał Barthes jako „prywatną stronę rytuału, który wznosi się z mitycznych głębi pisarza [...], jest ozdobnym głosem nieznanego i sekretnego ciała" (Barthes 2009, 100-101), co oznaczałoby mniej więcej tyle, że sekret języka tkwić ma w ciele samego pisarza i niebezpiecznie zbliżałoby ów proto-ponowoczesny ${ }^{1}$ formalizm do teorii somaestetycznej w wydaniu amerykańskiego pragmatysty Richarda Shustermana lub - z drugiej strony - do projektu krytyki somatycznej Adama Dziadka (Shusterman 2007, Dziadek 2014). Jak sygnalizowałem wcześniej, Barthes, analizując teksty markiza de Sade, starał się pokazać, w jaki sposób filozofia autora Justyny tworzyła swoisty system znaczeniowych form. Wyodrębnia za libertynem jednostki znaczące, odsłania relacje między nimi, pisze o „erotycznej gramatyce Sade'a [sic!]” - pornogramatyce - z jej erotemami i regułami ich łącznia (Barthes 1996). Filozof problem ten wykorzystuje właśnie po to, by mówić o tzw. przyjemności tekstu², z natury rzeczy wykluczającej poważną dyskusję o literaturze i jej właściwościach na rzecz kategorii doświadczenia czytelniczego. Dlatego też z punktu widzenia krytyki literackiej interesujące w koncepcji Barthes’a wydają się właściwie tylko poetologiczne, czy „pornogramatyczne” aspekty języka erotyzmu, seksualizmu i pornografii. Tego rodzaju ujęcie w ciekawy sposób łączy się także z nowoformalistycznym projektem Caroline Levine (Levine 2015) oraz pojęciem afordancji Jamesa Gibsona (Gibson 1977), co pozwala na wykorzystanie niektórych tez

${ }^{1}$ Cytaty pochodzą z debiutanckiej książki Barthes'a Stopień zero pisania, kiedy jeszcze o ponowoczesności nie mówiono.

${ }^{2}$ Podobnie jak Barthes zdaje się sądzić Susan Sontag, która jako jedna z pierwszych postulowała quasi-erotyczne doznanie tekstu, przeciwstawiając je lekturze „profesjonalnego interpretatora”. Słynny szkic zatytułowany Przeciw interpretacji zakończyła często później przywoływaną tezą: „Nie potrzebujemy hermeneutyki, ale erotyki sztuki” (Sontag 2018a, 26). 
Barthes'a podczas intencjonalistycznej, bliskiej tekstowi lektury dzieła literackiego. Afordancja jest terminem zapożyczonym przez nauki humanistyczne z teorii dizajnu i - ryzykując pewne uproszczenie - oznacza, że każda forma oferuje konkretną pulę możliwych znaczeń i aktywności z nią związanych, np. tekst aforduje lekturę, interpretację etc. Podobnie w wypadku de sade'owskiej pornogramatyki: poszczególne erotemy afordować mają sensy, zachowania czy skojarzenia, na przykład przyzwolenie, niezgodę, doświadczenie erotyczne.

Pornogramatyczną koncepcję języka wyraża Barthes także w najsłynniejszej swojej książce, w całości poświęconej zagadnieniu czytelniczej przyjemności i jej dostarczania przez autorkę lub autora - Przyjemności tekstu. $\mathrm{W}$ jednym $\mathrm{z}$ bardziej obrazowych fragmentów eseju - a przy tym w jednym z nielicznych, które mogą być przydatne krytykowi literackiemu - pisze:

[...] przyjemność lektury wypływa najwidoczniej z pewnych cięć (lub zderzeń): nienawistne sobie kody (wysoki i trywialny na przykład) łączą się, powstają pompatyczne i banalne neologizmy, treści pornograficzne zastygają w zdaniach tak czystych, że można by je uznać za wzorcowe zdania gramatyczne. Teoria tekstu powiedziałaby, że system językowy uległ redystrybucji. Takiej redystrybucji dokonuje się jednak zawsze przez cięcie. Zostają dwa brzegi: uczony, układny, plaża-plagiat (bo system językowy kopiuje się tu w jego stanie kanonicznym, wyuczonym przez szkoły, codzienność, literaturę, kulturę); i ten drugi brzeg: płynny, pusty (gotowy przyjąć dowolne kontury), który zawsze będzie miejscem, gdzie czeka się na śmierć mowy. Oba brzegi, ich reżyserowany kompromis, są konieczne. Ani kultura, ani jej destrukcja nie są erotyczne: erotyczna staje się szczelina między jedną i drugą. Przyjemność tekstu przypomina tę niemożliwą chwilę nie do wytrzymania- chwilę czysto powieściowa: smakuje ją libertyn ukresu zuchwałej machinacji, przecinając w momencie szczytowania stryczek, na którym wisi. (Barthes 1997, 11)

Podobne - choć nie tak materialistyczne ${ }^{3}$ - tezy wysnuwał Dziadek, zarysowując swój projekt krytyki somatycznej, w którym podkreślał m.in. znaczenie rytmu w tekstach literackich i związek ciała z eksplikacją doświadczenia: „jeśli mówimy o reprezentacji doświadczenia - pisał - to w żaden sposób nie da się pominąć ciała, które staje się dla ludzkiego doświadczenia zasadniczym punktem odniesienia” (Dziadek 2007, 69). Należy podkreślić, że

${ }^{3}$ Dziadek już na samym początku swojej argumentacji odżegnuje się od tez i idei zawartych w książce Krytyka i klinika Gilles’a Deleuze’a. 
Dziadek nie postuluje afektywnej lektury tekstu, tylko wskazuje na niezbywalną relację między cielesnością i słowem. Jest rzeczą jasną, że próby ujęcia ludzkiej podmiotowości za pomocą słów nie mogą się dziś obyć bez perspektywy somatycznej. Nie chodzi już bowiem tylko o to, by słowo stawało się ciałem, ale - dokładnie odwrotnie - by znaleźć odpowiedni język dla wyrażenia cielesnego doświadczenia dookolnej rzeczywistości. Dla Dziadka (co stanowi także nieodłączny kontekst dla moich rozważań o erotyzmie w polskiej poezji po roku 1989) „nie istnieją teksty literackie, w których ciało nie byłoby obecne” (Dziadek 2007, 69), podobnie jak dla Barthes’a (a wcześniej markiza de Sade) nie istnieją wypowiedzenia, które nie byłyby skonstruowane według porządku płciowo-seksualnego. A zatem namysł nad „erotemami” w polszczyźnie stanowić powinien również namysł nad sposobami wyrażania doświadczenia w języku.

Innym celem, jakiemu często służy wprowadzanie erotycznego arsenału do polskiej poezji współczesnej, jest ustawianie odbiorcy w niekomfortowej pozycji podglądacza. Istotne są także napięcia, które wytwarzają się między formą a literalnie rozumianą treścią czy sytuacją liryczną. $Z$ wrażeniem tym ma się do czynienia m.in. w niektórych wierszach Jarniewicza, gdzie autor przywołuje wyobrażenie wojny, lub na przykład w na wpół erotycznym wspomnieniu o matce z tekstu I syn, będącym w gruncie rzeczy eksplikacją pragnienia, by utwierdzić się we własnym byciu w świecie poprzez powrót do okresu dziecięctwa i fascynacji osobą matki. Pisze poeta:

Gdyby nie umarła trzydzieści lat temu, wiedziałbym, czy pożądanie, którym mnie dziś budzi, przebiłoby się do niej, od syna przez zły sen, i przejęło na własność jej ciało? Czy węszyłbym w jej szufladzie pełnej fig z falbankami? Zakładał jej szlafrok na ramiona, żeby kciukiem wyczuć gęsią skórkę? Meszek?

Przez próg przepuszczał i patrzył, jak pręży swój piżmowy grzbiet? Matka, sukinsynu? Wiedziałbym, na ogień, wstyd i na kamienie, że jestem, gdyby nie umarła za siedmioma górami, dawno, dawno temu. 
Nakreślona przez podmiot scena fantazji dotyczącej jego własnej matki wywołuje u odbiorcy dyskomfort: wrażenie, że uczestniczy w scenie intymnej w szczególny sposób, bo wynikający nie tyle z erotycznego pożądania, co z chęci odnowienia wyjątkowej relacji syna z matką, przez Japończyków określanej czasem słowem skinship (skórokrewieństwo), pod którym kryją się wspólne kąpiele, spanie, karmienie piersią etc. Ów czytelniczy dyskomfort wzmaga się jeszcze, gdy podmiot przedłuża fetyszystyczne poszukiwanie bliskości matki w scenie nie pozostawiającej żadnych wątpliwości, że mamy do czynienia z dorosłym mężczyzną; aż do oskarżającego, pełnego oburzenia i świętego gniewu wykrzyknienia skierowanego ku osobie mówiącej (a zatem najprawdopodobniej stanowiącego wyraz niezgody „zaprogramowanego” czytelnika): „Matka, sukinsynu?”. Puenta wiersza osłabia już to wrażenie, wyciszając sytuację liryczną i przenosząc sens wiersza w obszar dyskursywny, ale stopniowo budowane za pomocą rozmyślnych przerzutni napięcie: z jednej strony erotyczne, z drugiej - wynikające z czytelniczego oporu, tak czy inaczej pozostaje konstrukcyjną dominantą utworu.

Innym przykładem ustawiania odbiorcy w niekomfortowej sytuacji podglądacza może być także fetyszyzująca pozycja obserwującego w przedstawieniach Zagłady, jaką znaleźć można w wielu tekstach kultury dwudziestoi dwudziestopierwszowiecznej, głównie korzystających ze zdobyczy psychoanalizy. Na gruncie prozy ujęcie takie pojawia się choćby w twórczości Leo Lipskiego, w Zapiskach z martwego miasta Artura Sandauera lub Ślicznotce doktora Josefa Zyty Rudzkiej; z kolei na gruncie poezji - na przykład u Władysława Broniewskiego. Warte uwagi w tym względzie są także wszystkie dzieła literackie fetyszyzujące lub - odwrotnie - demitologizujące doniosłe, choć często tragiczne wydarzenia historyczne, takie jak powstanie warszawskie, wprowadzenie stanu wojennego lub okres stalinowskiego terroru. $\mathrm{Na}$ szczególną uwagę zasługuje w tym wypadku znakomita książka Co robi łączniczka z tekstami prozatorskimi Darka Foksa i quasi-pornograficznymi kolażami autorstwa Zbigniewa Libery, ukazująca w sposób niemal mechaniczny, szachowy czy oulipowski, co z czytelnikiem i czytelniczką robi różnie pojmowana narracja historyczna.

$\mathrm{Z}$ trojga wymienionych przeze mnie na początku niniejszego artykułu poetów najbliższa erotykom - zarówno genologicznie, jak i pod względem nastrojowości - jest twórczość właśnie Jarniewicza. Na kwestię tę bodaj jako pierwszy zwrócił uwagę Piotr Łuszczykiewicz w tekście Szkic do erotyku z końca $X X$ wieku, pomieszczonym w podręczniku Literatura polska 
1990-200o (Łuszczykiewicz 2002). Należy dodać, że krytyk wykazał się niemałą intuicją, zestawiając pisarstwo autora Makijażu ze znacznie bardziej rozerotyzowanymi w latach dziewięćdziesiątych twórcami przynależącymi do tzw. pokolenia „bruLionu”, w szczególności z Jackiem Podsiadłą, którego erotyki w najbardziej oczywisty sposób realizowały (i nadal realizują) gatunkowe schematy, a przez to okazywały się z jednej strony wtórne względem konwencji erotyzmu minionych epok, a z drugiej - utrwalały zmaskulinizowany, neoliberalny podmiot. W tym sensie nie wyzyskiwały form związanych ze sferą erotyczną w interesujący mnie tu sposób, a jedynie tematyzowały seksualność - głównie męską, bo taki punkt widzenia zawsze towarzyszył osobom mówiącym w wierszach Podsiadły - cechując się charakterystyczną dla brulionowców wsobnością i anarchizującą apolitycznością ${ }^{4}$.

W wypadku Jarniewicza było zgoła inaczej: mimo że poeta - już od nieco dziś zapomnianych juweniliów - nawiązuje do tradycji erotyku, ten wątek w jego twórczości bardzo długo, wyjąwszy wspomniany tekst Łuszczykiewicza, pozostawał nierozpoznany. Przyczyną tego był - jak sądzę - fakt, że autor Makijażu, jako anglista i uznany tłumacz poezji (przede wszystkim) brytyjskiej, nadal nie dość dobrze przeczytanej przez czytelniczki i czytelników w Polsce, wykorzystywał i przetwarzał awangardowe i postmodernistyczne chwyty poetologiczne związane z mniej całościowo i literalnie rozumianymi formami erotyzmu, korzystając z profanicznego obciążenia seksualności oraz cielesności, jakie ukute zostało przez kulturę i moralność mieszczańską, po to, by, wychodząc od dyskursu erotycznego, pogłębiać i uniejednoznaczniać sens swoich wierszy, nadając im subtelny wydźwięk społecznopolityczny. Strategia ta stanowi podstawę Makijażu, a także istotny punkt odniesienia dla całej tzw. trylogii relacyjnej ${ }^{5}$, a zatem zbiorów $N a$ dzień $d z i-$ siejszy i chwile obecna, Woda na Marsie oraz Puste noce.

Innego rodzaju erotyzm znaleźć można w twórczości Sosnowskiego. Mimo że poeta chętnie sięga po figury związane z cielesnością, większość jego wierszy i próz poetyckich trudno nazwać erotykami sensu stricto. Co prawda często wykorzystuje on konwencję dziewiętnastowiecznego eroty$\mathrm{ku}$, ale raczej po to, by wykreować sytuację liryczną mającą posłużyć do

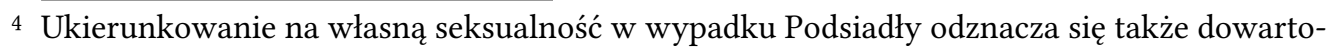
ściowaniem tematyki autoerotycznej. O tym aspekcie twórczości autora Dobrej ziemi dla murarzy pisał Tomasz Dalasiński w artykule Autoerotyczność. Trzy odsłony (Krasicki - Podsiadto - Wiedemann) (Dalasiński 2015).

5 Określenie Marty Koronkiewicz i Pawła Kaczmarskiego z wyboru wierszy Jarniewicza zatytułowanego Sankcje. 
poetyckiej gry z tradycją - w tym sensie strategia ta staje się raczej próbą przekroczenia stereotypowego myślenia o liryzmie poezji jako takiej niż samych gatunkowych ram. Najistotniejszymi w tym kontekście wątkami dotyczącymi twórczości autora poems są Barthes'owska kategoria przyjemności tekstu - niejednokrotnie poruszana w artykułach krytycznoliterackich poświęconych Sosnowskiemu, zwłaszcza w kontekście hermetyczności jego poezji - a także późnoawangardowy erotyzm formy poetyckiej w znaczeniu poetologicznym oraz socjologiczny, eksherentny aspekt twórczości Sosnowskiego, związany m.in. z uwodzicielskim sposobem, w jaki autor czyta swoje teksty publicznie.

O wymienionych tutaj zagadnieniach pisze m.in. troje krytyków towarzyszących poezji Sosnowskiego od dawna: Jacek Gutorow, Grzegorz Jankowicz i Marta Koronkiewicz (Guturow 2007; Jankowicz 2003; Jankowicz 2016; Koronkiewicz 2019). Komentując strategię liryczną twórcy, w Urwanym śladzie Gutorow posługuje się - oprócz słynnej metafory solarnej wyrażeniami takimi jak „zboczenie”, „flirt z czytelniczką/czytelnikiem”, kojarzony z karnawałem kamuflaż czy zacieranie śladów, „niezaspokojenie” lub próba osiągnięcia satysfakcji lekturowej poprzez rozwikłanie językowych kalamburów (Gutorow 2007, 143-160). Poezja Sosnowskiego wykorzystuje język erotyzmu, jego dynamikę oraz wieloznaczny potencjał. Wyzyskuje tropy literackie, które można interpretować jako konotujące czynności erotyczne. Do takich tropów należą m.in. jukstapozycje czy przerzutnie, czyli elementy stylu powodujące „zerwania” i „tarcia” pomiędzy poszczególnymi słowami, które tworzą owe Barthes'owskie szczeliny, będące dla autora Stopnia zero pisania najbardziej erogennymi, uwodzącymi miejscami języka.

Wiersze Sosnowskiego często zbudowane są także na dialogicznej opozycji pomiędzy jakimś podmiotowym „ja” lub „my”, a „ty”, przy czym granice pomiędzy owymi personami są zazwyczaj nieostre, a prowadzona przez bohaterów rozmowa okazuje się swoistym flirtem tożsamości w ramach jednostki, jak na przykład w wierszu Ostatki (11/12 sierpnia 1993) z tomu Sezon na Helu, gdzie w inicjalnej części utworu osoba mówiąca utożsamia się z jakimś innym, zabierając głos w pierwszej osobie liczby mnogiej, by wreszcie wprowadzić „ty”, które jednak domyślnie obecne jest już w otwierającym liryk wersie, zaczynającym się jakby w pół zdania, od dialogicznego „ale”:

Ale kiedy będzie robił przegląd swoich ulubieńców to chyba nas nie znajdzie, choć lubiliśmy spektakle sezonów, gwiezdne zapusty, szum nieba broczącego światłem tamtej sierpniowej nocy. 
W książce I jest moc odległego życia $w$ tej elegii Koronkiewicz ten aspekt podmiotu wierszy Sosnowskiego nazywa nieciągłością, co uruchamia także koncepcję sobowtóra w filozofii Georges'a Bataille'a ${ }^{6}$ oraz związane z nią pojęcia ciągłość i nieciągłość (przez jaką rozumie autonomiczność, jednostkowość, śmiertelność etc.), które to - zdaniem autora Historii oka - determinują ludzką tożsamość (Bataille 2015, 17 i nn.). Idąc dalej, francuski filozof zauważa, że zwierzęca nieciągłość i pragnienie ciągłości wpływają nie tylko na jednostkę pozostającą w relacji do rzeczywistości, ale także na to, co tę relację konstytuuje, czyli na język, z jego zerwaniami i tarciami. Mówiąc najprościej: w ujęciu Bataille’a doświadczenie wewnętrzne to poznanie przez trwogę lub ekstazę, natomiast samo poznanie filozof zrównuje z przedstawieniem, eksplikacją. Oznacza to tyle, że doświadczenie jest w istocie komunikacją; że tak czy inaczej przeżycie powstaje w języku, choć język jako narzędzie niedoskonałe - pozostaje zaprzeczeniem samego siebie, doświadczeniem niedoświadczalnego. Idąc tym tropem, można stwierdzić, że tak pojęte „doświadczenie języka” jest stanem pomiędzy nieciągłością bytu i pragnieniem ustabilizowania go. Podobnie dzieje się w wierszach Sosnowskiego, gdzie podmiotowość i tożsamość bohatera/bohaterów determinuje m.in. swoiste rozczłonkowanie doświadczenia rozumianego jako poszukiwanie życia, co przekłada się na język poetycki i obrazowanie, które ze względu na zagęszczenie sensów w początkowej fazie recepcji poezji Sosnowskiego odbierane było jako „zmechanizowane”.

Gutorow wiele miejsca poświęca także sposobowi, w jaki Sosnowski recytuje swoje wiersze. Wątek ten - zauważony po raz pierwszy właśnie przez autora Urwanego śladu - okazał się też jednym z głównych tematów zorganizowanej w 2010 roku konferencji, której pokłosiem jest tom o wiele mówiącym tytule Wiersze na głos (Śliwiński 2010). Jak przypomina Koronkiewicz, Krzysztof Hoffman pisał wówczas o głównym bohaterze sympozjum, posiłkując się wziętymi od Barthes’a pojęciami „pisanie-na-głos” oraz „ziarno głosu”, które są „erotyczną mieszaniną tembru i języka”. Za trzy główne cechy poezji Sosnowskiego uznawał - również Barthes'owskie: „(1) materialność, (2) niesemantyczność (która nie jest asemantycznością, kwestionowaniem sensu, lecz dryfem znaczenia w bok), (3) fonetyzm”, a poetykę wierszy autora poems wiązał - niebezzasadnie - z erotyką (Śliwiński 2010, 119-120) ${ }^{7}$.

${ }^{6}$ Koronkiewicz nie podejmuje tego tropu, skupiając się na innych wątkach związanych z nieciągłością podmiotu Sosnowskiego (Koronkiewicz 2009, 40-50).

7 Kwestia głosu - rozumianego jako „wyjście z sytuacji [lirycznej ku czytelniczce/czytelnikowi - K.P.]" pojawia się też w tekście Adama Lipszyca zamieszczonym w tej samej książce (Śliwiński 2010, 38-47). 
Warto dodać, że wszystkie te intuicje ściśle łączą się z pornogramatyczną (czy somaestetyczną) koncepcją języka. Tymczasem Gutorow problematyzuje sposób, w jaki Sosnowski czyta swoje wiersze, kojarząc głos z mutacją, którą przywołuje w dwóch znaczeniach: przejścia, odmiany (i w ten sposób postrzega na przykład nawiązania do kultury antycznej, staropolskiej czy romantycznej - jako zmutowane echa) oraz zmiany wysokości i skali głosu, występującej w okresie dojrzewania płciowego (co ukierunkowuje interpretację Gutorowa na problem „organiczności”, fizjologii i cielesności). Krytyk niejednokrotnie podkreśla też, jak ważnym aspektem poezji Sosnowskiego jest sposób autorskiej recytacji - żywa, hipnotyczna, niemal uwodzicielska obecność poety (Śliwiński 2010, 219-236; Koronkiewicz 2019, 10). Podążając tym tropem, nietrudno zauważyć, że także wyzyskanie konwencji erotyku stanowi w wypadku Sosnowskiego sposób na przesunięcia „kadłubków znaczeń”.

Z kolei dyskursowi pornograficznemu najbliższa pozostaje twórczość Oparek, co jest nieoczywiste o tyle, że porn studies zajmuje się właściwie wyłącznie pisarstwem męskim, związanym z androcentryzmem, tradycyjnymi rolami płciowymi (aktywność mężczyzny, bierność kobiety) oraz skonwencjonalizowanym modelem tekstów pornograficznych (zarówno literackich, jak i filmowych czy innych).

Rozumienie pojęcia „pornografia” - wykraczając poza potoczne skojarzenia związane z tym terminem - problematyzuje Susan Sontag w słynnym eseju Wyobraźnia pornograficzna (Sontag 2018b). Badaczka wyróżnia trzy rodzaje pornografii, którą ujmuje jako „zagadnienie z dziedziny historii społecznej”, „zjawisko psychologiczne” (wiąże je ze specyficzną charakterystyką instancji nadawczo-odbiorczych, definiowanych poprzez dewiacje seksualne i poczucie braku) oraz „modalność czy też konwencję w sztuce” (Sontag 2018b, 47). Sontag występuje w obronie konstruktu wyobraźni pornograficznej oraz literatury zwanej pornograficzną, świadoma wszelkich wyłączeń, jakich przedmiotem jest ów gatunek literacki. Spośród argumentów „moralnych polityków”, przeciwnych uznaniu literatury pornograficznej za pełnowartościową twórczość, wymienia: (1) znikome funkcjonalne znaczenie gatunku, który ma w zasadzie jedynie podniecić czytelnika i nie wnosi wartości estetycznej, etycznej czy poznawczej; (2) słabą oś konstrukcyjną Sontag przywołuje w tej kwestii sąd Theodora W. Adorno, który twierdził, że literaturę pornograficzną wyróżnia pretekstowe zawiązanie fabuły, następujące po nim ciągnące się wydarzenia oraz brak wyraźnego domknięcia 
(z punktu widzenia porn studies zwłaszcza z tym ostatnim nie można się zgodzić: „klasyczna” konwencja pornograficznych tekstów kultury zawiera niezbywalny element wyraźnego domknięcia, który charakteryzuje ejakulacja); (3) niewyrafinowanie; (4) instrumentalne wykorzystanie języka dla wywołania czytelniczej przyjemności; oraz (5) nieposiadających głębi psychologicznej bohaterów literackich, sprowadzonych do przedmiotowych ról (Sontag 2018b, 52). Sontag wywodzi powszechność tych poglądów wśród brytyjskich i amerykańskich krytyków z nieuświadomionego być może przekonania, że - zdaniem badaczki - za najwybitniejszą w przestrzeni społecznej konwencję literacką uznaje się realizm (Sontag 2018b, 53). Tymczasem większość argumentów wysuwanych przeciwko literaturze pornograficznej można też odnieść do innych gatunków i konwencji (awangardowych eksperymentów formalnych, literatury science-fiction itd.), a równocześnie wskazać na takie realizacje literackie, które należałoby określić pornograficznymi, a których nie dotyczą wymienione wyżej zarzuty (jak np. słynne prozy Bataille'a Historia oka czy Madame Edwarda). Argumenty konserwatywnych krytyków, jakie przytacza Sontag, do pewnego stopnia są oczywiście słuszne, ale tylko pod warunkiem, że bierzemy pod uwagę te teksty kultury, które konwencję pornograficzną traktują z pełną powagą (właśnie w zgodzie z paradygmatem realistycznym) - należy wyraźnie podkreślić, że czym innym jest obliczona na szokowanie i łatwa w komercjalizacji obsceniczność kultury masowej, a czym innym awangardowy erotyzm form poetyckich czy świadome postmodernistyczne przetwarzanie pornografii.

Oparek nie tylko wyróżnia się spośród autorów zainteresowanych seksualnością jako pisarka o zupełnie innej poetyce erotyzmu, ale też na tle współczesnych pornografów - właśnie jako pisarka. Perspektywa pornograficzna jest nadal domeną przede wszystkim pisania męskiego; a szkoda, bo pełne erotycznego napięcia wiersze i niezwykły poemat Berlin porn, m.in. przekształcający motyw walki klas poprzez zagarnięcie przez proletariat prawa do perwersji i czyniący bohaterem nowoczesne wcielenie symbolicznego patrona owego przesunięcia - Kuby Rozpruwacza - ukazują, jak bardzo uderzający i odświeżający jest to punkt widzenia. Seksualizm i pornografia w twórczości autorki Czerwi w ciekawy sposób realizuje jeszcze jeden aspekt tego typu pisarstwa: jego pragmatystyczny charakter, który wynika z późnokapitalistycznego uprzedmiotowienia i utowarowienia seksu, ciała, poszczególnych ról kobiet i mężczyzn, narracji lirycznej prowadzonej z punktu widzenia obserwatora. Istotny w tym wypadku staje się - podobnie jak na 
przykład u Jarniewicza - zmysł wzroku, tradycyjne narzędzie uprzedmiotowienia. Oparek odwraca ten wektor, poniekąd utowarowiając same wiersze, czyniąc je przedmiotami z ducha pornograficznymi, mającymi m.in. dostarczyć czytelniczce lub czytelnikowi podniety, która ostatecznie odwróci się przeciwko niej czy niemu.

Okulocentryzm jako typowo pornograficzną, czy wręcz transgresyjną (tu: w sensie nieekstatycznym), pozycję podmiotową problematyzował w swojej filozofii Bataille. W interpretacjach zawartych w słynnej książce Literatura $i$ zło poruszał też temat erotyzmu jako narzędzia oporu z jednej strony, z drugiej zaś jako praktykę seksualną (wraz ze wszystkimi konsekwencjami, jakie powstają w wyniku zderzenia tych potencjalności). Filozoficzny i pogłębiony sposób czytania Bataille’a zaproponował m.in. Tomasz Swoboda, którego interpretacja krąży właśnie wokół zagadnienia oka i uprzedmiotawiającego spojrzenia w kulturze europejskiej; dowodzi, że Bataille'owskie widzenie jest nieustannie poddawane przez autora gwałtownym eksperymentom, a oko jako organ staje się w jego twórczości właściwie samostanowiącym o sobie podmiotem - choć często także i przedmiotem różnych ekscesów seksualnych (Swoboda 2010). Choć w twórczości Oparek oko nie pełni w żadnym bodaj miejscu funkcji symbolicznej i nie jest tematyzowane, to jednak widzenie, obserwowanie i podglądanie, podobnie jak u Bataille'a, często stają się osobnymi podmiotami tej poezji.

W kontekście poezji pisanej przez kobiety oraz w związku z faktem, że dyskurs o cielesności i erotyzmie pozostaje nadal silnie zmaskulinizowany, niezwykle użyteczne okazują się narzędzia feministyczne i queerowe - a także szerzej: związane z emancypacją prekarnych bądź wykluczonych grup społecznych - w szczególności zaś pojęcie „przechwycenie”. Do najważniejszych i bodaj najbardziej wpływowych dyskusji dotyczących tego terminu należą eseje Judith Butler: Uwikłani w płeć. Feminizm i polityka tożsamości (Butler 2008), a także - szczególnie przydatne w kontekście kobiecej poezji pornograficznej - Walczące stowa. Mowa nienawiści i polityka performatywu (Butler 2010). Druga z wymienionych tu książek operuje détournement m.in. w kontekście przechwyceń języków wykluczenia, nienawiści i utowarowienia ukutych w dobie dominacji patriarchatu; języków takich jak choćby dyskurs pornograficzny. Przechwycenie tego typu tropów w poemacie Berlin porn Oparek oraz przekształcenie ich w taki sposób, że zaczynają zwalczać same siebie, stając się podwójnymi agentami seksualności kobiecej, jest jedną z najważniejszych cech tego pisarstwa. 
Nie sposób w niedługim artykule naszkicować w najmniejszym nawet stopniu wyczerpującą mapę lirycznych gier erotycznych w polskiej poezji najnowszej, ani też w pełni ukazać istotę tak opisywanego zjawiska. Krytyczny potencjał erotyzmu - zbudowany przede wszystkim na napięciach pomiędzy tym, co zgodnie z pozostałościami kultury filisterskiej moralnie poprawne, a tym co perwersyjne, stabuizowane i przez to $\mathrm{z}$ jednej strony pociągające, z drugiej zaś rewolucyjne oraz polityczne - ujawnia się przede wszystkim tam, gdzie pozornie być go nie powinno, gdzie rozumiana po kantowsku cielesność wiersza zyskuje moc dekonstrukcji mitów, tożsamości i struktur językowych, unieważniając literalną treść lub rezonując z nią, dając ostatecznie nową jakość i nowe sensy. W tym sensie erotyzm ponowoczesnej poezji polskiej - zgodnie z powyższymi tezami - należy rozumieć jako somaestetyczne współistnienie ciała i języka, które objawia się nie w prostodusznym odwoływaniu się do sfery seksualnej, ale na wynikających z różnorodnych formalnych zabiegów przesunięciach znaczeń. 


\section{Bibliografia}

Barthes, Roland. 1996. Sade, Fourier, Loyola. Tłum. Renata Lis. Warszawa: KR.

— 1997. Przyjemność tekstu. Tłum. Ariadna Lewańska. Warszawa: KR. 2009. Stopień zero pisania oraz Nowe eseje krytyczne. Tłum. Karolina Kot. Warszawa: Aletheia.

Bataille, Georges. 2015. Erotyzm. Tłum. Maryna Ochab. Gdańsk: słowo/ obraz terytoria.

Butler, Judith. 2008. Uwikłani w płeć. Feminizm i polityka tożsamości. Tłum. Karolina Krasuska. Warszawa: Krytyka Polityczna.

2010. Walczace stowa. Mowa nienawiści i polityka performatywu. Tłum. Adam Ostolski. Warszawa: Krytyka Polityczna.

Dalasiński, Tomasz. 2015. „Autoerotyczność. Trzy odsłony (Krasicki - Podsiadło - Wiedemann)”. [w:] Seksualność w najnowszej literaturze polskiej, red. Tomasz Dalasiński, Aleksandra Szwagrzyk i Paweł Tański, 231-243. Toruń: Literatura-Krytyka-Kultura.

Debord, Guy. 2006. „Społeczeństwo spektaklu”. [w:] Guy Debord, Społeczeństwo spektaklu oraz Rozważania o społeczeństwie spektaklu, 31-144. Tłum. Mateusz Kwaterko. Warszawa: Państwowy Instytut Wydawniczy.

Dziadek, Adam. 2007. „Soma i sema - zarys krytyki somatycznej”. [w:] Literackie reprezentacje doświadczenia, red. Włodzimierz Bolecki i Ewa Nawrocka, 69-82. Warszawa: Wydawnictwo Instytutu Badań Literackich PAN, Warszawa.

2014. Projekt krytyki somatycznej. Warszawa: Wydawnictwo Instytutu Badań Literackich PAN.

Gibson, James J. 1977. „The Theory of Affordances”. [w:] Perceiving, Acting, and Knowing, red. Robert Shaw i John Bransford, 67-82. Hillsdale: Lawrence Erlbaum.

Gutorow, Jacek. 2007. „Andrzej Sosnowski. Wiersz wychodzi z domu”. [w:] Jacek Guturow, Urwany ślad. O wierszach Wirpszy, Karpowicza, Różewicza i Sosnowskiego. Wrocław: Biuro Literackie.

Jankowicz, Grzegorz, red. 2003. Lekcja żywego języka. O poezji Andrzeja Sosnowskiego. Kraków: Zielona Sowa.

-2016. „Posłowie”. [w:] Andrzej Sosnowski, Zmienia to postać legendarnych rzeczy, red. Grzegorz Jankowicz. Poznań: Wielkopolska Biblioteka Publiczna i Centrum Animacji Kultury. 
Jarniewicz, Jerzy. 2018. Sankcje. Wybór wierszy i wypowiedzi. Wybór i oprac. Marta Koronkiewicz i Paweł Kaczmarski. Stronie Śląskie: Biuro Literackie.

Koronkiewicz, Marta. 2019. I jest moc odległego życia $w$ tej elegii. Uwagi o wierszach Andrzeja Sosnowskiego. Wrocław: Fundacja na Rzecz Kultury i Edukacji im. Tymoteusza Karpowicza.

Levine, Caroline. 2015. Forms. Whole, Rhythm, Hierarchy, Network. Princeton: Princeton University Press.

Łuszczykiewicz, Piotr. 2002. „Szkic do erotyku z końca XX wieku”. [w:] Literatura polska 1990-20oo, red. Tomasz Cieślak i Krystyna Pietrych, 366-379. Kraków: Zielona Sowa.

Shusterman, Richard. 2016. Świadomość ciała. Dociekania z zakresu somaestetyki. Tłum. Wojciech Małecki i Sebastian Stankiewicz. Kraków: Universitas.

Sontag, Susan. 2018a. „Przeciw interpretacji”. [w:] Susan Sontag, Przeciw interpretacji i inne eseje, Tłum. Małgorzata Pasicka, Anna Skucińska i Dariusz Żukowski, 11-26. Kraków: Karakter.

2018b. Wyobraźnia pornograficzna. [w:] Susan Sontag, Style radykalnej woli, Tłum. Dariusz Żukowski, 47-90. Kraków: Karakter.

Sosnowski, Andrzej. 2009. Pozytywki i marienbadki (1987-2007). Wrocław: Biuro Literackie.

Swoboda, Tomasz. 2010. Historie oka. Bataille, Leiris, Artaud, Blanchot. Gdańsk: słowo/obraz terytoria.

Śliwiński, Piotr, red. 2010. Wiersze na głos. Szkice o twórczości Andrzeja Sosnowskiego. Poznań: Wielkopolska Biblioteka Publiczna i Centrum Animacji Kultury. 


\title{
Abstract, keywords, about the author
}

\begin{abstract}
The forms of eroticism. Critical potential of eroticism in polish contemporary poetry

The year 1989 is a symbolic turning point in the discourse of sexsuality in Poland as well as important moment in history of an erotic as a genre: from the conventionally understood love-themed poem, through vulgar eroticism of the artists associated with 'bruLion', to sophisticated usages of convention, which purpose is to exploit critical potential of eroticism and to involve into a socio-political discussions. In the article the author presents the ways of eroticism, sexuality and pornography functioning as forms of resistance in polish contemporary poetry on the example of works by three poets: Jerzy Jarniewicz, Andrzej Sosnowski and Joanna Oparek. The author refers e.g. to the Roland Barthes' category of the pleasure of the text, Marquis de Sade's pornogrammar and Georges Bataille's philosophy. The claim of the author is to show how the contemporary poetry transforms the classical conventions of an erotic for ideological purposes.
\end{abstract}

Keywords: eroticism, Jerzy Jarniewicz, Joanna Oparek, Polish contemporary poetry, pornography, Andrzej Sosnowski

Karol PoręBA, literary critic, $\mathrm{PhD}$ candidate in the University of Wrocław's Faculty of Letters, editor-in-chief in Ossolineum Publishing House, he is interested in 2oth century and contemporary poetry, sociology of literature and philosophy.

E-MAIL: karol.poreba@uwr.edu.pl 